Nordic Journal of Religion and Society (2011), 24 (1): 57-74

Mia Lövheim and Marta Axner

\title{
Halal-TV: Negotiating The Place OF RELIGION IN SWEDISH PUBLIC DiscourSE
}

\begin{abstract}
In the fall 2008 the program Halal-tv, where three young, Muslim women discussed Swedish society and culture, caused several debates in Swedish media. This article analyzes the first debate taking place in op-ed articles in the Swedish daily Svenska Dagbladet and blog posts linking to these. The analysis focuses on the understandings of the place of religion in public discourse expressed in the debate. The authors conclude that the debate, on the one hand, confirms a polarized understanding of Swedish values as opposed to religious values. On the other hand, there are indications that Halal-tv opened up a space for negotiations of the role of the media in representing religion, and the place of religion in Swedish culture. In analyzing perspectives and issues brought up in the debate this article can contribute to further research on media as arena for negotiations of the place of religion in post-secular society.
\end{abstract}

Keywords: Islam; religion; public service media; mediatization; public sphere

\section{Introduction}

In the fall of 2008, Swedish Public Service television broadcast the program Halal-tv, a series of seven episodes where three young, Muslim women presented and discussed Swedish society and culture. Shortly before the first episode was aired a debate started in the Swedish press and on blogs about the program. The purpose of this article is to analyze the debate about Halal-tv, focusing on the main issues and lines of conflict expressed by the participants. Starting from the assumption that public service media in the Swedish context can be seen as a primary expression of mediated public discourse, we discuss how this case may illustrate issues and positions in a wider public discourse on religion in contemporary Sweden. ${ }^{1}$ This discussion is set in the context of recent discussions within the sociology of religion on the resurgence of religion in the public sphere of late modern, Western society and the implications for understanding relations between religion and modernization (Berger 1999; Casanova 1994; Davie 2007). Media has become an increasingly important arena for public engagement with religion in modern society, which has been demonstrated in studies within international research on media, religion and culture (Hoover et al. 1997; Larsson et al. 2006; Mar- 
riage and Mitchell 2003). Nevertheless, few studies within current sociology of religion actually analyze the role of the media in this situation. Based on theories of the need for «complementary learning processes» in public discourse in post-secular society (Habermas 2006) and processes of mediatization shaping the conditions of communicating religion in modern society (Hjarvard 2008), the aim of this article is to contribute to the debate on the place of religion in contemporary society.

\section{Background: Religion and media in contemporary Sweden}

Sweden is often described as one of the more secularized countries in Europe in terms of the importance of religion in the public sphere. In 2000 the national Lutheran Church of Sweden was separated from the state. The majority of the population is still members of the Church of Sweden but no more than 5.6 percent regularly attend services (Bromander 2011). During the past two decades, however, immigration has led to a growing visibility of religion, most notably Islam, in Swedish society. Researchers approximate that 250,000 - 350,000 Muslims live in Sweden (Larsson 2005: 30). Parallel to this development, public discourse on religion has focused on the presence of Islam in society. In January 2009, a contested report from the Swedish National Defence College claimed evidence of increasing radicalization of Muslims in segregated areas of the city of Malmö (Ranstorp and Dos Santos 2009; Lövheim 2009). Media research shows a stereotyped and negative representation of religion in news media, where Islam in particular is presented as a fanatical and violent religion opposed to values central to modern Swedish society, such as democracy, tolerance and equality (Hvitfelt 1998; Levin 2006).

The other element framing the debate on Halal-tv concerns the changing role of public service media in an increasingly culturally diverse society. Traditionally, public service television and radio have been the dominating broadcast media in Sweden. During recent decades, an increase in the number of Swedish and international commercial TV channels has changed this situation, which challenges the role and policy of the Swedish public service television company SVT. Approximately 90 percent of Swedish households pay the license fee, and, according to the SVT web site: «SVT is together with the public service radio (SR) the most trusted Swedish media and enjoys very good support from the Swedish TV audience» (SVT 2011). SVT programming is non-commercial, and covers a wide variety of genres. Public service television in Sweden, as in many European countries, has a designated task to be an arena for impartial journalism and to represent different parts of the population, but to do so in an unbiased and fair manner. The Swedish Radio and Television Act stipulates the assertion of democratic values and gender equality, and the prevention of all forms of discrimination. In April 2008, SVT further assumed a new diversity policy stating that the organization should welcome and respect differences concerning gender, age, ethnicity, religion or faith, sexual orientation and disability (Hultén 2009: 4). 


\section{Halal-tv - the program}

Halal-tv was aired in seven weekly episodes during the fall of 2008 on SVT2, starting on November 3rd 2008 (SVT 2008a). The program was inspired by the Dutch PSB program «De Meiden van Halal» (The Girls of Halal), broadcast by Netherland Programme Service (NPS) in 2005 and 2006 (Hultén 2009). Every 30-minute episode had a particular theme, approached through interviews with politicians, scholars and others, and discussions between the three participants. All three, Cherin Awad, Khadiga El Kabiry and Dalia Kassem, were born in Sweden to parents of immigrant origin. They were in their early/mid-twenties, had a university education, and were practicing Muslims, wearing the hijab. None had a journalistic background or training (SVT 2008b). The three participants met and interviewed different people, and they were filmed and presented on their way to and from the interviews in a documentary manner. A final, eighth episode was recorded, but never aired, and replaced by a debate on the program: «After Halal-tv,» which was aired on December 22nd 2008.

The information on SVT's website shows that the aim of the producers of Halal-tv was to address the relationship between conventions surrounding Swedish identity and cultural values and an increasingly multi-cultural population. The presentation of the program closes with the sentence: «Cherin, Dalia and Khadiga each have a deep and vibrant Muslim faith. They share this with a large group of Swedes. But they do not represent anyone else than themselves. On Halal-TV, viewers will meet three individuals who, in various personal ways, twist and turn often ingrained ways of thought in Sweden» (SVT 2008a).

The program generated several debates in other media. This article focuses on a debate that started before the series was aired, and another debate following the first episode. The latter debate concerns a controversy where two participants, referring to their religion, refrained from shaking hands with a male interviewee, writer Carl Hamilton, who reacted with indignation (Expressen 2008). After the first episode, 33 complaints against the show were filed to the Swedish Broadcasting Commission, SBC. According to the rules for public service radio and TV in Sweden, all broadcasts must adhere to certain conditions - such as impartiality, accuracy and balanced treatment of controversial subjects (Myndigheten för radio och tv 2011). The complaints mostly concerned the impartiality clause and whether it was in accordance with the rules that the participants took a stance in controversial issues and were participating as practicing Muslims. The SBC later decided not to issue any formal criticism of Halal-TV on any of the grounds of complaint. The main reason was the documentary character of the program, which meant that the participants did not fall under the same requirements of impartiality as a host representing the broadcasting company (Decision by the Swedish Broadcasting Commission 27.4.2009).

\section{Theory: Religion in a mediated public sphere}

In this article we will use the concepts «public discourse on religion» as well as «public sphere.» By discourse on religion we refer to communicative events (written and 
spoken language) used to represent religious beliefs, practices, actors and institutions from a particular point of view (Fairclough 1995: 56; Lövheim 2004: 33). The concept of the «public sphere» as used by Jürgen Habermas (1989) refers to a realm of social life in which private people come together as a public, independent of state authorities, to engage in issues of common concern. The public sphere is thus conceived as the space in which public opinion can be formed, characterized (in the ideal case) by inclusivity and disregard of status. Our starting point in this article will be that the debate over Halal-tv can be seen as a discourse on religion that takes place in the public sphere, by which is meant a public exchange of ideas and opinions in Swedish society. This discourse is shaped by, but also plays a part in, constituting public opinion on religion in Swedish society.

In 1994 Spanish-American sociologist José Casanova initiated a discussion on the de-privatization of religion with his empirical comparative study of the place of religion in public life (Casanova 1994). Arguing against the privatization of religion thesis, i.e. that religion is becoming less of a public matter, he claims that religious actors are re-entering the public sphere of society. While mainline and former state churches have lost formal influence, they use media, civil society and other forms of public life to influence society (Casanova 1994). This process of de-privatization exists side by side with other processes of religious change. In his later work, Casanova (2006: 21) argues that this process will continue as Europe becomes more multicultural due to migration and globalization. Casanova claims that only religious groups that accept the basic rules of modern democracy and pluralism, thus in some ways letting go of their claim to ultimate authority, can have a place in the public life of modern democracies (1994: 219). However, de-privatization also implies that the understanding of secularity that has become the default option, as well as a core value of European self-understanding, is challenged, as the presence of religion within the public sphere calls for a re-negotiation of the meaning of the secular (Casanova 2009). Linda Woodhead, British sociologist of religion, has discussed how debates on covered women in Europe should be interpreted in the light of an underlying and dominant «narrative of secular European progress» (Woodhead 2009). As her discussion relates closely to the case studied in this article, we will return to her arguments in our analysis. Jürgen Habermas also discusses (2006) how the experience of living in a "postsecular society» challenges previously held understandings of the role that religious traditions, actors and convictions play in the public sphere, primarily in Western Europe. According to Habermas, the institutional separation between religion and politics, based on the notion that the state applies strict impartiality towards religious communities, is a necessary precondition for a democratic society. This principle of secularity implies that religious arguments and convictions can be expressed in the public sphere. What is required is «the epistemic ability to consider one's own faith reflexively from the outside and relate it to secular views» (2006: 10), most notably that secular reasons based on «the egalitarian individualism and universalism of modern law and morality» (2006: 14), has priority in the political arena. From this follows that religious convictions must be translated into a generally accessible language if they are to enter the institutionalized political public sphere of discussion and decision-making. 
However, the principle of egalitarianism means that this process of translation is «a cooperative task» in which non-religious citizens must also participate. A post-secular society requires «complementary learning processes» (2006: 4) of adopting an epistemic stance towards fellow citizens in which also secular citizens are expected to enter into «a self-reflective transcending of a secularist understanding of modernity» (2006: 15). In Habermas' discussion these processes are primarily pre-political; they take place in public discourses among citizens rather than in the institutional political public sphere.

What is missing in Habermas' as well as Casanova's discussion on changing conditions for the role that religious arguments and actors play in the public sphere of modern, post-secular societies is the role of the media in shaping public discourses among citizens. Danish media scholar Stig Hjarvard (2008) uses the concept of mediatization to describe the long-term implications of increasing mediation, or the performance of human communication through interaction with a medium, in modern society. One important consequence of this development is that core elements of social and cultural activities increasingly become dependent on the logic of the media (Hjarvard 2008: 13-14). Mediatization also has significant implications for the public presence of religion, implying a shift from religious institutions as the primary sources of religious content in the public sphere to a situation where religious themes or symbols are produced by the media themselves. Furthermore, religious representations are molded and formatted according to different genres, not least the genres of popular culture. This means that religion in the mediated public arena has become more individualized and oriented towards entertainment and consumption. Finally, the media has increasingly become the environment in which interaction and communication takes place in a society. Hjarvard argues that the media performs functions previously fulfilled by religious institutions, such as ritualizing everyday life, or constructing core values of society. The validity of Hjarvard's thesis of a mediatization of religion for different religious and media contexts has been challenged (Hoover 2009). Lynn Schofield Clark (2008), for example, has discussed whether an online discussion forum may create more pluralistic and nuanced approaches to religion than conventional mass media due to the wider range of participants and perspectives involved (Clark 2008).

Against this background, the questions posed in this article can be summarized: What understandings of the role of religion in public discourse are expressed in the debate on Halal-tv? Are there examples of «complementary learning processes» in the debate? How are processes of mediatization shaping the debate, and are there differences between various forms of mediated discourse, that is blogs and op-eds? Finally, the aim is to discuss how this case may illustrate the changing place of religion in modern Sweden.

\section{Methods and data}

The following analysis is not based on the content of the program Halal-TV itself, but on the debate preceding the program. The debate started when Dilsa Demirbag-Sten, 
liberal journalist of Kurdish origin and well-known discussant of migration and religion, criticized the program on October 31st in an op-ed article in Sweden's second leading newspaper Svenska Dagbladet (Demirbag-Sten 2008a). This article received three responses - one by Joakim Sandberg, publisher at SVT (Sandberg 2008), one by Stefan Swärd, Chairperson of Evangelical Christian think-tank Claphaminstitutet (Swärd 2008) and, finally, one by the participants in the program: Cherin Awad, Khadiga El Kabiry and Dalia Kassem (Awad et al. 2008). Demirbag-Sten responded to two of these articles (Demirbag-Sten 2008b, 2008c). In total, these six articles form one part of the empirical data for the following analysis. On the webpage of Svenska Dagbladet links to blog posts referring to each article are displayed using the web tool Twingly. Links to a total of 88 blog posts were found on the web versions of the six articles by the time we made our first collection of data in July 2009. These blog posts referring to the articles make up the second part of our data.

The case consists of three different media forms: television, op-eds and blogs, and we analyze the two latter. Op-ed articles and blogs represent different media technologies and genres. Although the ideal has been to form a public space for the exchange of ideas of citizens, op-eds remain a traditional print medium, strongly edited and, to a large extent, a place for already-established voices of the media or related societal spheres (Wahl-Jorgensen 2004). Blogs, on the other hand, are part of a development towards a digital-media environment characterized by a higher degree of «user-led content creation» (Bruns 2008: 1). The implications of this development, in terms of transformations in the topics, style, genres and range of participants taking part in public discourse, is an ongoing discussion within media studies (Rasmussen 2008). Therefore, it is of interest to study if the discussion on Halal-tv in the blogs differs from the arguments and opinions expressed in the op-eds.

Our aim is to use a particular mediated discourse to illustrate broader issues in the public discourse on religion in contemporary Sweden. It is important to point out that the empirical material on which the following analysis is based represents a limited part of the mediated discourse generated by the program Halal-tv. We do not claim that the conclusions drawn from the findings fully represent the different ways in which the program contributed to the public discourse on religion in contemporary Swedish society. However, we argue that, despite these limitations, this case study can be used to illustrate tendencies, issues and identify themes for further research. Our choice of this particular debate has been motivated by the fact that it represents one of the most polarized debates on the program, and it preceded the actual program. Therefore, the arguments were based more on opinions about the program than the actual content of, or public reactions to, the program. Relating to the theory of representation, this case may illustrate tacit, pre-conceived meanings, conventions and identities that are ascribed to particular signs, such as a covered young woman, in a certain context (Hall 1997: 5). We are aware that the case is limited but, as we will show, it also highlights the ways in which the media frame the wider discussion of religion in public life in Sweden. 


\section{Findings}

\section{The op-eds in Svenska Dagbladet}

The initial op-ed article written by Demirbag-Sten is entitled «Wrong front figures in SVT-program». The main point in Demirbag-Sten's three articles (Demirbag-Sten 2008a, 2008b, 2008c) is that the three young women hosting Halal-TV should not be presenting a program about religion on public service television. She argues that these women were chosen for their religiosity, not their journalistic skills, and that religion in public service media should only be presented by politically and religiously noncommitted and impartial journalists. In another TV program five years prior to this debate, one of the hosts, Chenin Awad, made a statement interpreted as support for Sharia laws, even in cases such as stoning women for infidelity (she later retracted that statement). Demirbag-Sten uses this statement, along with the participants' views on separating the genders, as her main reason for calling them fundamentalists and extremists. She argues that they make all Muslims seem «deeply believing, veiled homophobic total abstainers from alcohol who think women should be virgins until marriage and who support stoning for infidelity» (Demirbag-Sten 2008a).

Her opponents in the discussion raise different arguments. In his reply on October 31 st, the publisher Joakim Sandberg (2008) stresses that the program is first and foremost a documentary. Furthermore, he argues that if space is given to new or different voices in television, the discussion on what constitutes Swedishness will be more nuanced. The third participant in the debate, Evangelical opinion-maker Stefan Swärd (2008), argues on November 3rd that no one is completely objective and so-called objective journalists also speak from a particular viewpoint. Giving broadcasting space to Muslim women is a matter of freedom of religion, and, since Christian services are broadcast without critical commentary, this should also apply to a program like Halaltv (Swärd 2008). He does, however, require of the hosts an acceptance of human rights and, thus, the acceptance of stoning would disqualify a person from being a representative of SVT. Finally the participants write a reply on November 5th where they argue that religion should be no obstacle for doing TV: «what else should be impossible for religious people to do?» they ask rhetorically. This is a matter of freedom of speech (Awad et al. 2008).

As this presentation shows the debate starts out with a critique of the choice of participants in the program but develops into a discussion about if, how and by whom religion can be represented in public service media. In this discussion the different standpoints expressed reveal diverging understandings of religion and the place of religion in the public sphere. We will return to a discussion of these perspectives in the analysis of the debate.

\section{The discussion in the blogs}

In the section that follows, we present the blog material, grouped into four major categories. $^{2}$ The majority of bloggers were critical of Halal-tv and many supported Demirbag-Sten's argument. A large group of critical bloggers were label anti-Islam bloggers (22 posts). Several are connected to the right-wing Populist Party 
(Sverigedemokraterna). Many of these write about how Islam is not consistent with Swedish values, where gender equality is often specified. Another recurring topic is the participants' view on Sharia laws.

Another critical group, although not as extreme as the anti-Islam bloggers, are the critical liberals (22 posts). These bloggers write about freedom of speech, the right to criticize religion and how SVT has not fulfilled its duty to impartiality with this program. A recurrent theme is political correctness and the difficulty of criticizing religion in Sweden. Almost all of them support Demirbag-Sten. Some are not as harsh in their critique and think the major problem is not Islam or religion, but that the participants are «extremists» in their views. Many blogs also discuss the handshaking controversy during the first episode, mainly supporting writer Hamilton's claim that the participants should follow Swedish custom and shake hands, even through some think he overreacted. There opinions are expressed in the following example:

These three ladies represent an extreme version of Islam where gender apartheid is one of the foundations. Refusing to shake hands is not just a symbolic gesture, but displays an ideology going against everything we have been fighting for as a democratic society. ....Accepting religious people does not mean rewarding religious movements which in their foundations are contrary to gender equality and ultimately equal rights for all humans (Henrik Emilsson 2008-10-3).

Blogs positive to the program and critizing Demirbag-Sten are fewer. One small but distinct group consists of the defenders of covering (3 posts) - Muslim women defending covering and also supporting Halal-tv and the participants. They defend women's (and everyone's) right to their religion and customs referring to freedom of religion and the right of the individual.

The larger group defending the program or discussing it without taking sides is more heterogeneous, but can be labeled the defenders of diversity (26 posts). They are mostly critical of Demirbag-Sten, arguing that many voices should be heard on public service television. Some discuss racism and integration while others discuss issues such as the handshaking controversy or the hijab. Several stress the complexity of gender issues in Islam. These bloggers have doubts about how representative the participants in the show are, but generally support Muslim women participating in the media. One example:

\footnotetext{
Islam is of course provocative to many. To me because I find it hard to accept that women must wear a veil, for example... Still, if you choose your religion out of conviction, you have made a free choice. Ugh, these are difficult questions. But now that Halal-tv has started: let's open the windows and clear the air and talk about things. Let's have conversations about these issues, listen to each other. Because that is how I have chosen to understand Halal-tv: a way of starting to listen to each other (Kulturbloggen 2008-11-04).
}

The debate in the blogs can be assumed to display a broader range of opinions than the op-eds, as a result of the differences between the two forms of media. As can be seen, the views concerning the kind of religion that should be allowed in public discourse are more outspoken in the blogs. Also, the boundaries between the mediated discourse rep- 
resented by the program Halal-tv, public service media and the wider public sphere in terms of public exchange of ideas and opinions in Swedish society and culture, become blurred.

\section{Analysis}

A closer analysis of the arguments expressed in op-eds and blogs reveals that the debate concerns two different but closely related issues. The first concerns views on the program as such and focus on questions relating to how religion should be represented in public service media. The second issue concerns the role of religion in public service media.

\section{Public service media and religion: Conflicting aims and ideals}

The op-ed articles show that one major issue of debate is the genre or kind of program Halal-TV represents. Demirbag-Sten's initial article starts out with a critique of SVT's choice of «front figures» or hosts in the program. A closer analysis of her arguments shows that her view is based on a particular understanding of the aims and ideals of public service media and on the place of religion in relation to these. She defines the program as a journalistic production and argues that religion represents a particular ideological standpoint that is not compatible with the objectivity and neutrality that is required of a journalist or host working for SVT. Swärd also describes Halal-TV as a mainly journalistic product but, in contrast to Demirbag-Sten, he does not see religion per se as incompatible with this genre. The producer of the program, Sandberg, bases his arguments on an understanding of the program as a documentary, and emphasizes that this genre has requirements other than those of a journalistic production such as a news broadcast.

At the heart of the discussion about the genre of Halal-TV lies the issue of whether the program can be seen as following the mandate, rules and guidelines of Swedish public service media. The arguments reveal a possible conflict between, on the one hand, journalistic ideals of impartiality, professionalism, factuality and critical investigation, and, on the other hand, the aim to assess equality and encourage diversity of opinions (Hultén 2009). While impartiality, professionalism and, above all, critical standpoints are seen as crucial ideals for «serious journalism,» as advocated by Demirbag-Sten (2008b), the values of equality and diversity relate closely to the ideals of «public journalism.» Public journalism can be described as a journalistic orientation that emphasizes the participation of «ordinary people» in public discourse, and the responsibility of the media to facilitate an open, unbounded arena to which all citizens have access and where all topics can be expressed (Haas 2007). This kind of journalism challenges the role of journalists as gate-keepers and distances itself from news criteria based on polarization and journalistic ideals of neutrality (Ihlebæk 2009).

As discussed by Ihlebæk (2009: 370), one of the dilemmas of implementing the ideals of public journalism concerns the choice of participants. On what grounds are «ordinary people» chosen, and how does this relate to the quality of the production? 
Also in the debate on Halal-TV, a key issue concerns the choice of the three participants and what they represent. Demirbag-Sten argues that the choice of front figures confirms stereotypes and reinforces norms of «real» Muslim women as deeply faithful, covered and opposed to gender equality and individual rights. Sandberg argues that the program challenges stereotypes and previous ways of representing minority groups in the media by «handing the microphone over» to three young Swedish women, who, in addition, are covered believers (Sandberg 2008). This challenges the role usually given to young women and Muslims by turning them into the main characters giving their perspective on Swedish society. Finally, the participants present themselves as «three of millions of strong, happy and believing women who are not oppressed» (Awad et al. 2008). This, they imply, challenges the thesis that Islam is a religion oppressing women as well as conceptions of Muslim women as isolated from society.

These arguments show that through the choice of front figures Halal-TV brought out tensions in the assignment of Swedish public service television between ideals of objectivity and values of diversity. The debate also shows how the key matter of dispute becomes religion and what it represents in the views expressed by the participants.

\section{Mediatization and religion}

If, as claimed in the theory on mediatization of religion, media becomes the prime mediator of religion in society, then the rules and aims of certain media genres also structure how religion comes to be represented in the public discourse. In traditional news journalism religion has been fundamentally controversial, since it is seen as representing subjective viewpoints and, thus, challenges standards of objectivity (Hoover 2006: 57-59). The discussion in the op-eds shows how these journalistic ideals are used in order to criticize the program's representation of religion as well as its place in public service media. However, in an increased culturally diverse and differentiated media environment, various aims and ideals are blurred. The tensions regarding aims and ideals in Swedish public service television brought out by Halal-TV can be unpacked by looking at the way youth, gender and religion are interconnected in the arguments. In the critique against the program, the combination of these aspects is seen as a challenge towards journalistic ideals of professionalism, objectivity and critical review. Previous research shows how genres like news and documentary programs have traditionally been associated with masculinity (Gill 2007). In this debate, it is interesting to note that the gender of the program hosts is seldom made an issue in itself. The word «woman» is primarily connected to «faith», «Muslim» or «covered» and, therefore, used to enhance a certain meaning of «religion». The religious beliefs of the participants seem to be the most important factor in making them «wrong front figures». Their religion, conservative attitudes and veils make them representatives of a particular view or ideology, which should not be advocated on public service television. The fact that they are young, non-professional and women reinforces this stereotype of Muslim women as dependent and unskilled. 
In the arguments for the program as challenging stereotypes, the fact that the program leaders are young, women and active actors is emphasized. Their religious beliefs and veils are downplayed or used to strengthen the argument that this program turns the tables and lets the «other» speak. This is clearly shown when the producer argues that the real issue concerns «whether a young woman, regardless of race or religion» should be able to play an active role in a media production (Sandberg 2008). The arguments of the producer and the program hosts of Halal-TV, show that they aim at challenging and transforming the traditional format, stereotypes, and conventional power structures of journalism. In so doing, they need to find a reason that is valid within the mandate of Swedish public service media. Their main argument draws on values of equality, plurality, emancipation and individual choice - values that, besides being central to public service and public journalism, are also central to late-modern Swedish culture (Pettersson 2000). In order to fit these values, the religious faith of the program hosts has to be subordinated to their gender, age and cultural position and made into an individual choice or perspective shown in the form of a documentary.

\section{The place of religion in public discourse}

The debate in the op-eds also reveals different fundamental positions and understandings among the participants regarding religion. A closer analysis of the arguments expressed reveals various understandings of, in particular, the kind of religion that is perceived to be acceptable in public discourse. Demirbag-Sten's initial critique of the program reveals a particular understanding of the kind of religion that should not be allowed, most explicitly as expressed in her description of the three young Muslim participants as fundamentalists and extremists. Furthermore, she argues that journalists having a religious faith are not a problem - as long as they keep it private and do not let it affect their work (Demirbag-Sten 2008c). Among the other participants, another understanding of religion can be discerned, namely that a religious faith per se should not disqualify a person from expressing her opinions in a public debate, and that this debate needs to be open to a broad range of convictions and arguments.

Our analysis of the discussion in the blogs shows that, for the most part, the same basic opinions are expressed in the articles. However, the views concerning the kind of religion that should be allowed in public discourse are more outspoken in the blogs. Many bloggers who argue against the program follow Demirbag-Sten's line of thought. Some are critical of religion in general while others are not, but most critics support the idea that religion should not affect public life and especially not state-owned public service television. Some of the more aggressive anti-Islam blogs express the idea that Muslims in general or Islamists want to «take over» Swedish or Western society and create Islamic states. Their arguments are based on the notion that religion (or at least Islam) is a threat to the public life of society. Others, especially in the diversity defenders-group, follow the position that freedom of religion and diversity are important in a modern, open society and that a plurality of voices, including religious ones, should have a place on television. Most of these bloggers seem to agree that religion is a matter 
of personal choice in the sense that everyone should be allowed to choose to live as religiously or non-religiously as they wish.

\section{Religion and modernity}

Our analysis of the op-eds and blog posts shows that different views on the program were raised, and that they relate to certain fundamental positions concerning the aims and values of public service media as well as the kind of religion that can have a valid place in public discourse.

How are we to understand the differences and similarities between these positions? An interesting parallel is Linda Woodhead's discussion on the debate in Britain concerning covered women. Woodhead shows that the values invoked by those opposing covering were mostly the same as those invoked by those defending covering (Woodhead 2009: 91-95). This implies that the underlying tension in the debate concerns how to interpret these values in contemporary society. Following Woodhead, values are not founded entirely on rational arguments but on emotions and collectivelyshared stories and symbols in a society. This is true for values of modern egalitarian individualism and morality as well as for religious values. The covering controversy in Britain, and in many other European countries, needs to be interpreted in light of an underlying and dominant «narrative of secular European progress.» According to this story, deeply connected to enlightenment and modernity, Europe has moved from the darkness of superstition in pre-modernity, connected with religion, oppression and hierarchy, to the enlightenment of rationality and liberation, associated with democracy, freedom, equality and the secular (Woodhead 2009). Seen in this light, Muslim covering does not only go against certain values but threatens the whole story of secular progress.

Woodhead's argument provides interesting perspectives for understanding the discussion of Halal-TV. Habermas' position (2006) that religious arguments in the public sphere must be adapted to certain validity claims in order to have a place in public life of the political arena can be found in the op-eds and the blogs. Many blogs - both those criticizing and those defending the program - discuss if shaking hands or covering are examples of extremism. Blogs referring, in particular, to an earlier statement by one of the hosts, Cherin Awad, on the stoning of women, do so by showing that this is an example of extremism not compatible with a modern, democratic society. The defenders of the program also distinguish between different forms of religion and claim that extremism has no place in public service television. Thus the idea of religion expressed in public, at least religion that does not accept and follow the basic principles of modern democracy described by Habermas (2006) and Casanova (1994: 228), is seen as a threat to modern society. The discussions also have many parallels to Woodhead's (2009) discussion of the British debate on covered women. Allusions to a story of secular or rational progress can be found in different forms in the material. It is most clearly expressed in the articles by Demirbag-Sten, and the critical liberal blogs. This concerns the argument that religion has no place, or only a marginal one, in the public sphere and is descri- 
bed as the opposite of democracy or an open society. Similar arguments can be seen in the postings of the defenders of diversity group. When stressing the importance of diversity for a free, open and modern society, they can be said to refer to this story. Very few bloggers question the idea of religion as a private matter. They discuss different religious expression and whether they are threats or assets in society, but rarely discuss the idea of religion as a fundamentally private matter as such.

\section{Discussion}

The previous sections analyzed the different understandings of the role of religion in public discourse expressed in the debate on the program Halal-TV. The aim of this section is to discuss these results in the context of the changing place of religion in contemporary, Swedish society. The broadcasting of a program on public service television where young Muslim women comment on Swedish society can, in itself, be seen as a sign of how religion in modern society appears in new, public arenas, as pointed out by Casanova (2006). The debate on the program illustrates the intensification of discussion on the place of religion in society in a «post-secular» situation. It also shows the need to discuss the principles and conditions structuring public discourse through «complementary learning processes,» as suggested by Habermas (2006:15).

An underlying issue in the debate is whether the program fulfilled such a democratic aim. The producers of Halal-tv clearly aimed at presenting a program that would widen the scope of perspectives and participants in this discourse and thereby contributing to the formation of a democratic, multi-cultural society. As the producer writes:

The debate about multi-cultural Sweden is crucial for this country; it needs multiple participants and multiple originators, men and women. It has not ended with Halal-TV, but it has taken yet another step towards also letting the people who live with the issues every day to have their say (Sandberg 2008).

Demirbag-Sten (2008c) concludes in her final comment that SVT has «primarily reduced Muslims to a group of extremists» through the program. In her analysis of Halal-TV, Swedish media researcher Gunilla Hultén (2009) concludes that the program failed in its aims since the main outcome of the series was a homogeneous representation of Islam, where Muslim beliefs and values were contrasted with Swedish secular attitudes. The three program hosts «acted as religious/ethnic/cultural mirrors...reflecting negative aspects of Swedishness» (Hultén 2009: 14).

The analysis in this article supports, on the one hand, Hultén's conclusion. Our analysis of the debate preceding the program shows that several arguments criticizing the program were based on an understanding of public service television as committed to certain fundamental Swedish values and that Muslim or religious values pose a challenge to these values. The connection between Halal-TV as a particular form of mediated discourse and the public discourse in a wider sense can be seen in the arguments of the producers and participants in the program, with reference to the ideals of public journalism, and the media as an active agent shaping the public sphere. In the blogs, 
too, the boundaries are blurred between Halal-tv, public service media, and the public sphere, by which is meant Swedish society and culture in a wider sense. This outcome can be interpreted as a consequence of mediatization of religion in the sense that public discourse on religion in post-secular society is being shaped by the rules, aims and ideals of the media. In the debates, the ideals of «serious journalism», which demand that religion must be presented from a critical perspective in order to ensure objectivity, are still strong and seem more in line with the dominant opinions concerning the place of religion in the Swedish public sphere. The editorials and blogs criticizing as well as defending Halal-TV find common ground in the argument that religion should, first and foremost, be represented in public service media as a private matter.

On the other hand, our analysis complements and nuances the conclusion that the program contributes to polarization of Swedish and religions values. As we have shown, there are indications that Halal-TV opened up a space for negotiation of the place of religion in public service media. This negotiation emerges, for example, in the discussion of how, and by whom, religion can be represented in public service media. The analysis shows that the choice of young women from an ethnic minority group as front figures can be legitimized with reference to the assignment and ideals of public service media, and also to the cultural identity of Sweden as a modern, progressive, equal and tolerant country. Here our analysis shows that the media also need to adjust to the «post-secular» situation of contemporary society. The ideals of «public journalism» evoked in the debate shows that this awareness can imply attempts to include a broader variety of expressions and opinions on religion in the media, including those that advocate a more public role for religion, and a critique of secular values. The blog discussion following the debate in the op-ed articles also indicates the blurring of different genres due to the development of new media. These media hold the potential for a wider range of voices and views on religion to be expressed in public discourse.

The debate on Halal-TV further shows that the program opened up a space for negotiation of the principles and values underpinning public discourse in contemporary Sweden; primarily whether values such as freedom and equality should include religious beliefs and practices. Here our analysis connects to Habermas' discussion on complementary learning processes, where religious as well as non-religious participants in the discourse learn to adopt an epistemic stance towards each other in which they enter into «a self-reflective transcending» of their fundamental convictions. On the one hand, the debate shows how religion in the Swedish public discourse still seems to denote values that are fundamentally opposed to modernity, enlightenment, equality, freedom and democracy. In this case, religion is perceived to be something completely different from a secular, rational world view. The fact that many different attitudes to religion may exist among Muslims as well as people of other faiths is left aside. On the other hand, some debaters question the idea of religion as incompatible with the range of identities, experience, emotions, traditions and lifestyles that exist in a modern society, which leaves more room for an understanding of a common ground between religious and non-religious views and values. Still, the negotiation seems to take place within certain boundaries, as many actors in the discussions explicitly make a distinction between «acceptable» religion and extremism. 


\section{Conclusions}

The aim of this article has been to analyze the different understandings of the role of religion in public discourse, as expressed in a debate preceding the TV-program HalalTV in Sweden during the fall of 2008. Our findings show that the debate initially concerned different ideals and criteria for journalistic production in public service media. These different views are grounded in certain assumptions concerning the kind of religion that might be accepted in the Swedish public discourse. These connections between the program and the Swedish public sphere indicates how media, in this case public service television, is conceived as a primary arena for the public presence and role of religion in Swedish society. The debate also shows how the media becomes a site for negotiations about how values and principles of a modern, democratic society can be applied in a post-secular situation.

The implication of our analysis is that studies of the place of religion in contemporary society need to take into account how processes of mediatization shape the conditions for public discourse among citizens (Hjarvard 2008), as well as the possibility for «complementary learning processes» (Habermas 2006) to take place among them. On the one hand, mediatization may enhance a polarization where religious values are seen as incompatible with values fundamental for a democratic, modern, Swedish society. On the other hand, the debate on Halal-tv opened up a discussion concerning the meaning and implementation of these aims and ideals, in public service media and in society. While the story of European progress as described by Woodhead (2009) still seems to be dominant and taken for granted in Swedish public discourse on religion, there are indications that it is under negotiation. Though the basic principles of the story remain unquestioned, the relation between values such as freedom, openness and religion seems to be under discussion. Perhaps not Halal-TV itself, but the debate that it initiated in a wider mediated discourse and the range of opinions expressed in op-eds and blogs, may have contributed to an expansion and differentiation of conceptions of religion and secularity in Swedish culture and society. These findings illustrate how mediatization of religion cannot be seen as a homogeneous process. More research is needed on how the interplay between media and religion may contribute to «complementary learning processes» in the public discourse on religion in a post-secular society.

\section{Notes}

1 This study is a part of the research program Impact of Religion: Challenges to Society, Law and Democracy, based at the Uppsala Centre for Research of Religion and Society, Uppsala University. It is also integrated in the project The role of religion in the public sphere: A comparative study of the five Nordic countries (NOREL), headed by Professor Inger Furseth, KiFO, Norway.

2 We found 88 unique blog postings. Several blog posts linked to more than one article, and some links were no longer functioning. The posts were sorted into 4 groups. 15 posts were difficult or impossible to fit into any of these groups, and thus are not discussed here. A list of all blog posts is available from the authors. 


\section{References}

Awad, Cherin, Khadiga El Khabiry and Daria Kassem 2008. Vad är det mer än tv-program vi inte fär göra? (What else other than TV are we not allowed to do?) [online]. Available from: http://www.svd.se/opinion/brannpunkt/artikel_1 992 305.svd [Accessed 9 July 2009].

Berger, Peter L. 1999. The desecularization of the world: resurgent religion and world politics. Grand Rapids: Eerdmans.

Bromander, Jonas 2011. Forthcoming. Medlem 2009 (Member 2009) [preliminary title]. Stockholm: Verbum.

Bruns, Axel 2008. Blogs, wikipedia, second life, and beyond: from production to produsage. New York: Peter Lang.

Casanova, José 2009. Are We Still Secular? Exploring the Post-Secular: Three Meanings of 'the Secular' and their possible transcendence (Very rough draft). Paper presented at a workshop with Jürgen Habermas at the Institute for Public Knowledge, New York University October 22-24, 2009.

Casanova, José 2006. Rethinking Secularization: A Global Comparative Perspective. After Secularization. The Hedgehog Review 8:7-22.

Casanova, José 1994. Public Religions in the Modern World. Chicago: University of Chicago Press.

Clark, Lynn Schofield 2008. Religion, philosophy, and convergence culture online: ABC's Lost as a study of the processes of mediatization. Northern Lights 6:143-163.

Davie, Grace 2007. The sociology of religion. London: Sage.

Demirbag-Sten, Dilsa 2008a. Fel frontfigurer i SVT-program (Wrong front figures in SVT-Program) [online]. Available from: http://www.svd.se/opinion/brannpunkt/artikel_1 972 377.svd [Accessed 9 July 2009].

Demirbag-Sten, Dilsa 2008b. Förmår djupt troende skapa balans i Halal-tv? (Can profound believers manage to create balance in Halal-TV?) [online]. Available from: http://www.svd.se/ opinion/brannpunkt/artikel_1 979 203.svd [Accessed 9 July 2009].

Demirbag-Sten, Dilsa 2008c. SVT reducerar muslimer till extremister (SVT Reduces Muslims to Extremists) [online]. Available from: http://www.svd.se/opinion/brannpunkt/artikel_2 005 075.svd [Accessed 9 July 2009].

Expressen 2008. Hamilton i storbråk med SVT:S muslimska programledare [Hamilton in major quarrel with SVT's muslim program hosts] November 3rd. [online]. Available from: http:// www.expressen.se/Nyheter/1.1 355 609/hamilton-i-storbrak-med-svt-s-muslimska-programledare [Accessed 12 November 2010].

Fairclough, Norman 1995. Media discourse. London: Edward Arnold.

Gill, Rosalind 2007. Gender and the media. Cambridge: Polity.

Haas, Tanni 2007. The pursuit of public journalism: theory, practice and criticism. Abingdon: Taylor \& Francis.

Habermas, Jürgen 2006. Religion in the Public Sphere. European Journal of Philosophy 14: 125.

Habermas, Jürgen 1989. The structural transformation of the public sphere: an inquiry into a category of bourgeois society. Cambridge: Polity Press.

Hall, Stuart 1997. Representation: cultural representations and signifying practices. London: Sage.

Henrik Emilsson. [online] Available from: http://integrationsbloggen.blogspot.com/2008/10/ halal-tv-tjejerna-knappast.html [Accessed 17 February 2010]. 
Hjarvard, Stig 2008. The mediatization of religion: A theory of the media as agents of religious change. Northern Lights 6: 9-26.

Hoover, Stewart M. 2009. Complexities: the case of religious cultures. In Mediatization: concept, changes, consequences, K. Lundby (ed.), 123-138. New York: Lang.

Hoover, Stewart M. 2006. Religion in the media age. London: Routledge.

Hoover, Stewart M., Alf Linderman and Knut Lundby 1997. Rethinking media, religion, and culture. Thousand Oaks, CA: Sage.

Hultén, Gunilla 2009. Doing the right thing the wrong way. Representations of Islam and the dilemmas of sharing good practices in European public service broadcasting. Paper presented at ECREA -Diaspora, Migration and the Media section, Nov 6 - 7, 2009.Utrecht University, Netherlands.

Hvitfelt, Håkan 1998. Den muslimska faran: Om mediebilden av islam (The Muslim Danger: on the Media Image of Islam). In Mörk magi $i$ vita medier (Dark magic in white media), Y. Brune (ed.), 72-84. Stockholm: Carlsson.

Ihlebæk, Karoline Andrea 2009. Folkejournalistikk i NRK - redaksjonelle valg og utøvelse av kontroll (Public Journalism at NRK - editorial selections and controlling power). Norsk medietidsskrift 16: 363-375.

Kulturbloggen (The Culture Blog) [online]. Available from: http://kulturbloggen.com/?p=3899 [Accessed 17 February 2010].

Larsson, Göran 2005. The impact of global conflicts on local contexts: Muslims in Sweden after 9/11-the rise of islamophobia, or new possibilities? Islam and Christian-Muslim relations 16: $29-42$.

Larsson, Göran, Mia Lövheim and Alf Linderman 2006. Religion och medier: några perspektiv (Religion and media: Some perspectives). Lund: Studentlitteratur.

Levin, Anna 2006. Nya nyheter och gamla stereotyper (New news and old stereotypes). In Religion och Medier: nagra perspektiv (Religion and the media: Some perspectives), G. Larsson, M. Lövheim and A. Linderman (eds.), 165-183. Lund: Studentlitteratur.

Lövheim, Mia 2009. Mediatization and radicalization of religion. Paper presented at NordMedia '09, The 19th Nordic Conference for Media and Communication Research, Karlstad University, Sweden, August 13-15 2009.

Lövheim, Mia 2004. Intersecting identities: young people, religion, and interaction on the Internet. Doctoral Dissertation. Uppsala: Acta Universitatis Upsaliensis.

Marriage, Sophia and Jolyon P. Mitchell 2003. Mediating religion: conversations in media, religion and culture. London: T\&T Clark.

Myndigheten för radio och tv 2011. Regler för Regler för SVT, SR och UR (Rules for Swedish Television, Swedish Radio and Educational Radio) [online]. Available from: http://radioochtv.se/Tillsyn/Granskning-av-program/Reglerna/SVT-SR-och-UR/ [Accessed 12 January 2011].

Pettersson, Thorleif 2000. Svensken och religionen (The Swede and the religion). In Svenskt kynne. L. Lewin (ed.), 9-23. Uppsala: Acta Universitatis Upsaliensis.

Ranstorp, Magnus and Josefine Dos Santos 2009. Hot mot demokrati och värdegrund - en lägesbild från Malmö (Threat against democracy and core values - a situational analysis from Malmö) [online]. Centrum för Asymmetriska Hot och TerrorismStudier. Available from: http://www.fhs.se/documents/externwebben/nyheter/2009/hot-mot-demokrati-och-vardegrund-20 090 128.pdf [Accessed13 January 2011].

Rasmussen, Terje 2008. The Internet and Differentiation in the Political Public Sphere. NORDICOM Review 29: 73-83. 
Sandberg, Joakim 2008. Självklart att troende kvinnor ska få göra tv (Self-evident that women of faith are allowed to do tv) [online]. Available from: http://www.svd.se/opinion/brannpunkt/artikel_1 972 379.svd [Accessed 9 July 2009].

SVT 2008a. De vänder och vrider på invanda tankesätt (They twist and turn our usual ways of thinking) [online]. Available from: http://svt.se/2.96 077/1.1 225 562/sasongsinformation [Accessed 23 November 2010].

SVT 2008b Personliga presentationer (Personal presentations) [online]. Available from: http:// svt.se/2.96 077/1.1295 972/personliga_presentationer [Accessed 23 November 2010].

SVT 2011. The Swedish public service broadcaster- no other has a greater choice of genres [online]. Available from: http://svt.se/2.10 775/1.159 227/ the_swedish_public_service_broadcaster_-_sveriges_television_svt?lid=puff_159 902\&lpos=lasMer [Accessed 11 January 2011].

Swedish Broadcasting Commission, decision on Halal-tv 27 April 2009 [online]. Available from: registrator@radioochtv.se, decision number SB 349/09

Swärd, Stefan. 2008. Är en ateist mer objektiv än en troende muslim? (Is an atheist more neutral than a believing muslim?) [online]. Available from: http://www.svd.se/opinion/brannpunkt/ artikel_1 981 243.svd [Accessed 9 July 2009].

Wahl-Jorgensen, Karin 2004. Playground of the pundits or voice of the people? Comparing British and Danish opinion pages. Journalism studies 5: 59.

Woodhead, Linda 2009. The Muslim Veil Controversy and European Values. Swedish Missiological Themes 97: 89-105. 